\title{
A Study on the Toxic Effect of Different Doses of Diclofenac Sodium on the Development of the Kidney in the Postnatal Period
}

\author{
Estudio sobre el Efecto Tóxico de Diferentes Dosis de Diclofenaco Sódico \\ en el Desarrollo del Riñón en el Período Postnatal
}

Hesham N. Mustafa ${ }^{1}$; Isinsu Alkan²; Ömür Gülsüm Deniz²; Berrin Zuhal Altunkaynak²; Ebru Annaç \& Suleyman Kaplan²

MUSTAFA, H. N.; ALKAN, I.; DENIZ, Ö. G.; ALTUNKAYNAK, B. Z.; ANNAÇ, E. \& KAPLAN, S. A study on the toxic effect of different doses of diclofenac sodium on the development of the kidney in the postnatal period. Int. J. Morphol., 37(3):877-884, 2019.

SUMMARY: The toxic effects of different doses of diclofenac sodium (DS) on the kidney on the postnatal period (0-7 days) by morphometrical and immunohistochemical methods were investigated. For this purpose, 15 female adult wistar albino rats were used and divided into 5 main groups. Group Ia served as normal control, physiologic group Ib received normal saline, group II received low dose (3.9 $\mathrm{mg} / \mathrm{kg})$, group III received medium dose $(9 \mathrm{mg} / \mathrm{kg})$ and group IV received high dose $(18 \mathrm{mg} / \mathrm{kg}$ ). Male offspring's from 0-7 days after birth were used in this study. On the 8th day of postnatal life, all animals were anesthetized. Then, the kidney samples were analyzed. Haematoxylin and eosin staining showed degeneration and necrosis, apparent atrophy of the glomeruli, mononuclear cell infiltration, congested vessels, increased fibrous tissue and distortion of the proximal convoluted tubules with interruption of the brush margin of the DS treated group. Increased level of Caspase- 3 and upregulation of TNF- $\alpha$ with different doses of DS. In light of our findings, DS may lead to adverse effects that are dose-dependent in the prenatal subjected kidney to this drug.

KEY WORDS: Diclofenac sodium; Proximal convoluted tubules; Apoptosis;Cyclooxygenase.

\section{INTRODUCTION}

Diclofenac sodium (DS) is an antipyretic, painrelieving, anti-rheumatic and anti-inflammatory drug with inhibitory effect on prostaglandin biosynthesis. Currently, is considered one of the oftenly used non-steroidal antiinflammatory drug (NSAID) (Katzung \& Trevor, 2016). It is used in many conditions as acute attacks of gout and ureteric colic, rheumatoid arthritis, osteoarthritis and postoperatively (Bhagat et al., 2003). Kidney is the target organ for the adverse effects of DS (Oaks et al., 2004).

DS is metabolized by the liver into 4-hydroxy diclofenac and other hydroxylated form then undergo glucuronidation or sulfation followed by biliary and urinary excretion (Mehinto et al., 2010). The maximum daily dose for adults ranges from 150-200 mg/day. Children aged $>1$ year should be given $0.5-2 \mathrm{mg} / \mathrm{kg}$ body weight daily, in $2-3$ divided doses.

The effects of DS on renal histoarchitecture and function are worth attention. Studies showed thickening of the glomerular basement membranes (GBMs) with mild focal tubular necrosis (Farag et al., 1996). In addition, interstitial nephritis, lipid peroxidation and papillary necrosis were observed. Clinically, hematuria and proteinuria associating the use of diclofenac and reflecting the resultant renal dysfunction were noticed (Sabry et al., 2014).

The aim of the current study is to declare the effects of different doses 1/25,1/10 and 1/5 of the (lethal dose) LD50 dose of DS on the renal tissues.

\section{MATERIAL AND METHOD}

Chemicals. Diclofenac sodium (DS) was purchased from FAKO (pharmaceutical company, Turkey).

Experimental Design. In this study, 15 female adult Wistar albino rats, 280-300 g of weight, obtained from Ondokuz

\footnotetext{
${ }^{1}$ Department of Anatomy, Faculty of Medicine, King Abdulaziz University, Jeddah, Saudi Arabia.

${ }^{2}$ Department of Histology and Embryology, Faculty of Medicine, Ondokuz Mayıs University, Samsun Turkey.

${ }^{3}$ Department of Histology and Embryology, Faculty of Medicine, Adiyaman University, Adiyaman, Turkey.
} 
MUSTAFA, H. N.; ALKAN, I.; DENIZ, Ö. G.; ALTUNKAYNAK, B. Z.; ANNAÇ, E. \& KAPLAN, S. A study on the toxic effect of different doses of diclofenac sodium on the development of the kidney in the postnatal period. Int. J. Morphol., 37(3):877-884, 2019.

Mayis University Experimental Animal Research Centre, were used. Rats were held in plastic cages inside rooms under standard conditions of temperature $\left(21 \pm 1^{\circ} \mathrm{C}\right)$ and humidity and applied with dark/light cycles of 12 hours. Animals were fed with tap water and standard pellet rat food. Afterwards, females were put in the same cages with males, in order for them to become pregnant. On the day after the mating, females with vaginal plaque were considered as on the day zero of their pregnancy. Our study was approved by Ondokuz Mayis University Animal Experiments Local Ethical Committee approval $N^{\circ}$. 2011/11.

The female adult rats in the study were selected randomly and divided into 5 different cages in groups of 3 rats each. Pure control group were subjected to no process. The serum physiologic group was intraperitoneally injected with $1 \mathrm{ml}$ normal saline during the same period. The experimental groups were injected with diclofenac sodium (DS) in respective doses of (3.6 $\mathrm{mg} / \mathrm{kg}, 9 \mathrm{mg} / \mathrm{kg}$ and $18 \mathrm{mg} / \mathrm{kg}$ ).

The groups can be summarized as:

Group Ia: Pure Control group (No process were performed) (n:3).

Group Ib: Physiologic group received $1 \mathrm{ml}$ normal saline injection $(\mathrm{n}: 3)$.

Group II: 3.6 mg/kg DS injection (n:3). (Represent 1/25 of LD50: lethal dose).

Group III: 9 mg/kg DS injection (n:3). (Represent 1/10 of LD50 dose).

Group IV: 18 mg/kg DS injection (n:3). (Represent 1/5 of LD50 dose).

The animals in all groups gave birth on the average 21 st day of their pregnancy. At this point, 30 oneweek old male offspring's that are randomly selected from the regarding mothers (six male offspring's from each group were selected) were subjected to euthanasia under high dose anaesthesia and were decapitated. After the kidneys were removed and put in labelled specimen containers with $10 \%$ Neutral buffered formaldehyde. The tissues were kept in formaldehyde for them to be fixed.

Sections were stained with hematoxylin eosin. 5 micron thick sections were taken for immunological and histopathological examinations.

The tissue sections were stained with H\&E to study the general architecture. Periodic Acid-Schiff (PAS) for observation of glycogen and Masson's Trichrome (MT) for distinguishing collagen. For each specimen, at least three to five slides were examined using an Olympus BX53 microscope equipped with DP73 camera (Olympus, Tokyo, Japan) (AbdEl-Moniem et al., 2015; Mustafa, 2015).

Immunohistochemical Examination. Using the streptavidin-biotin-peroxidase technique, the endogenous peroxidase activity was eliminated using $10 \% \mathrm{H} 2 \mathrm{O} 2$ for 15 minutes. Sections were then incubated for one hr with primary antibody against Caspase-3 (a rabbit polyclonal, Cat. no. 250573, Abbiotec-San Diego, USA; dilution 1: 200; cellular site is cytoplasmic) as a marker for apoptotic death. They were similarly incubated with primary antibody against TNF-a (Tumor Necrosis Factor alpha, a mouse monoclonal antibody; Dako, Carpinteria, California, USA; dilution ready to use $(5-10 \mu \mathrm{g} / \mathrm{ml})$; cellular site is cytoplasmic) as a marker for proinflammatory cytokines. Sections were incubated for 20 min in DAB chromogen (3, 30 diaminobenzidine) and then counter-stained with Mayer's hematoxylin. Negative control sections were prepared by omitting the primary antibody. Positive control standard laboratory slides were used for all stains to prove the success of the technique. All slides were examined under light microscopy and the presence of labeled cells was documented. Absence of staining was recognized as a negative result (-), while the presence of brown staining was recognized as positive result (+) (AbdEl-Moniem et al.).

Quantitative morphometric measurements. Ten nonoverlapping fields for each animal were selected indiscriminately and analyzed. The measurements were done with the use of Image-Pro Plus v6.0 (Media Cybernetics, Maryland, USA) and NIH ImageJ (v1.51) (http://rsb.info.nih.gov/ij/) associated with an Olympus BX53 microscope. The mean area percentage of immunostaining for TNF- $\alpha$ positive cells was evaluated. Furthermore, apoptotic cells (the mean percentage area of Caspase- 3 positive immune cells was calculated and analyzed for comparison with the control group) were counted in an area of $20000 \mu \mathrm{m}^{2}$ and selected randomly in the stained sections at X400 magnification. Reaction to PAS was evaluated and scored semi-quantitatively as follows: none (-); mild (+), moderate $(++)$, severe $(+++)$ (AbdEl-Moniem et al.).

Statistical analysis. Quantitative data were expressed as the mean \pm SD of different parameters for the treated groups. The data were analyzed using one-way analysis of variance (ANOVA) followed by Tukey's post-hoc test. The statistical analysis was performed using SPSS version 23 . The values were considered significant when $\mathrm{p}<0.05$. 


\section{RESULTS}

Both the pure control (Ia) and the physiologic group (Ib) revealed the same histological findings. Histologic assessment of control group revealed normal histological structures (Fig. 1A). Group II showed little degeneration in the tubular epithelium and congested vessels in the cortical interstitial tissues (Fig. 1B). Group III showed some focal tubular epithelial degeneration and necrosis with mild fibrosis (Fig. 1C). Group IV showed degeneration, widening, necrosis and an apparent atrophy of the glomeruli and tubules, nuclear pyknosis and mononuclear cell infiltration (Fig. 1D) (Table I).
PAS staining of the control did not show any damage in the brush margin on the apical surface of proximal tubules. The glycogen content was normal in proximal and distal tubules (Fig. 2A). Group II revealed that the brush margin was nearly normal. There was a negligible decrease in the content of glycogen in the proximal and distal tubules (Fig. 2B). Group III revealed that the brush margin was damaged at some places. There was a negligible decrease in the content of glycogen in the proximal and distal tubules (Fig. 2C). Group IV showed that the brush margin was indistinct, scanty and severely damaged. The glycogen

Table I. Histopathologic assessments of the experimental parameters induced by different doses of diclofenac sodium.

\begin{tabular}{lcccc}
\hline & Control group I & Group II & Group III & Group IV \\
\cline { 2 - 5 } & $\mathrm{N}=10$ & $\mathrm{~N}=10$ & $\mathrm{~N}=10$ & $\mathrm{~N}=10$ \\
\hline Tubular degeneration and widening & - & + & + & +++ \\
Tubular necrosis & - & - & + & +++ \\
Atrophy & - & - & - & + \\
Nuclear pyknosis & - & - & - & ++ \\
Mononuclear cell infiltration & - & + & + & + \\
Congested vessels & - & ++ & + & + \\
Reaction to PAS & ++ & + & + & + \\
Fibrous tissue & - & + & + \\
\hline
\end{tabular}

Changes were graded as follows: (-) showing no change and (+), (++) and (+++) indicating mild, moderate and severe changes respectively.
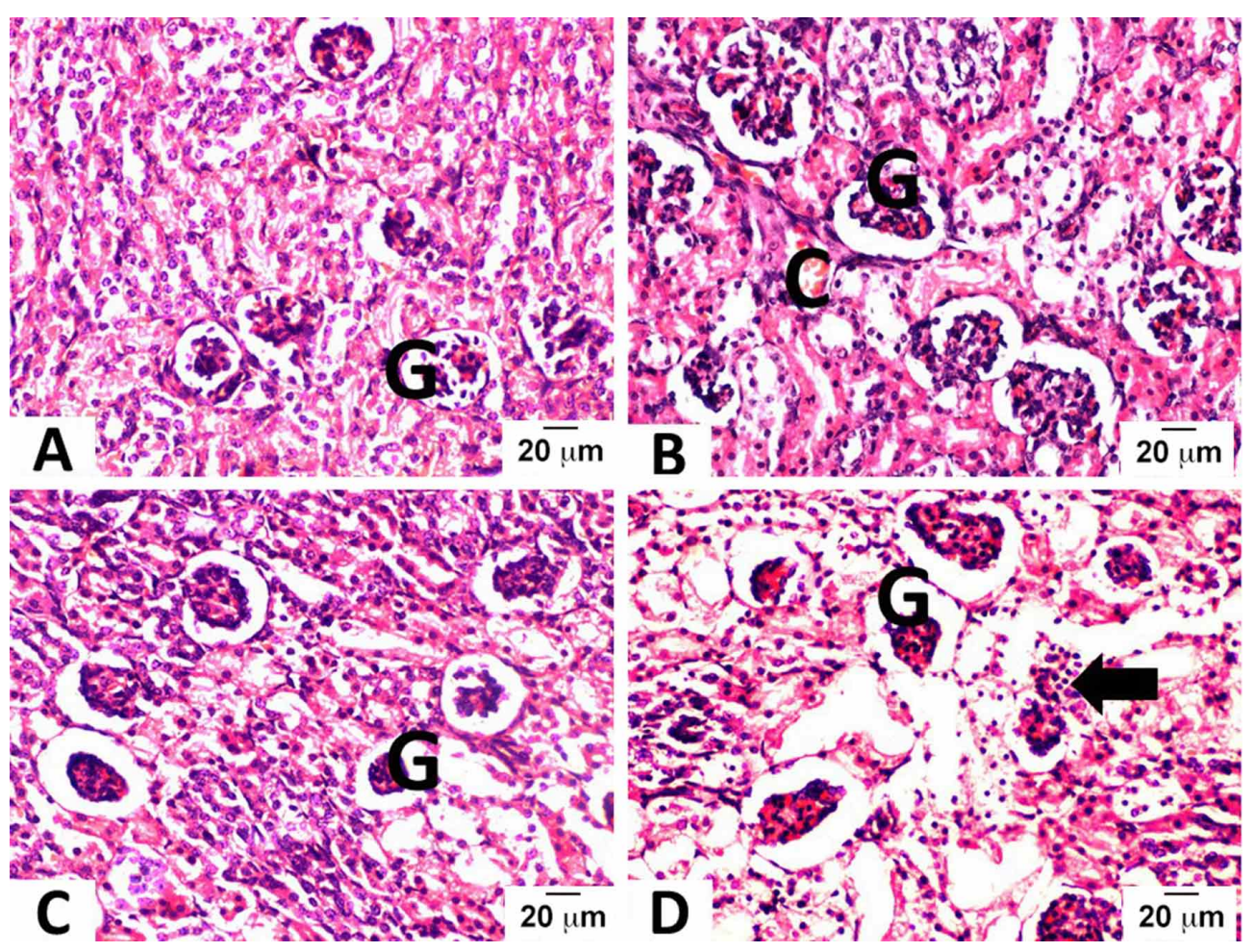

Fig. 1. (A). Photomicrograph of the control group showed normal histological structures, glomeruli (G). (B). Section of group II revealed few degeneration in the tubular epithelium and congested vessels in the cortical interstitial tissues (C). Section of group III showed some focal tubular epithelial degeneration and necrosis. (D). Section of group IV revealed degeneration, widening, necrosis and an apparent atrophy of the glomeruli (G) and tubules, nuclear pyknosis and mononuclear cell infiltration (arrow) (H\&E. Scale bar $20 \mu \mathrm{m})$. 
MUSTAFA, H. N.; ALKAN, I.; DENIZ, Ö. G.; ALTUNKAYNAK, B. Z.; ANNAÇ, E. \& KAPLAN, S. A study on the toxic effect of different doses of diclofenac sodium on the development of the kidney in the postnatal period. Int. J. Morphol., 37(3):877-884, 2019.

content was decreased in both proximal and distal tubules (Fig. 2D) (Table I).

Control groups showed regular collagen fibers deposition in the mesangial matrix of the glomeruli (Fig. 3A). Group II revealed collagen fibers around the blood vessels (Fig. 3B). Group III displayed collagen deposition around the tubules and the blood vessels (Fig. 3C). Group IV showed condensation of glomerular collagen fiber deposition both mesangial (global or segmental) with apparently thickened parietal layers of Bowman's capsules, and sparse areas of connective tissue around congested blood vessels (Fig. 3D) (Table I).

Immunohistochemical results. In the control group, a faint reaction was found in the cytoplasm of the renal cells (Fig. 4A). Group II showed mild immunopositive stain for TNF- $\alpha$ was found in the cytoplasm of different cells (Fig. 4B). Group III revealed apparent increase in the intensity for TNF- $\alpha$ (Fig. 4C). Group IV showed intense immunopositive stain for TNF- $\alpha$ was found in the cytoplasm of different cells. The cells showed dense brown granules (Fig. 4D). These results were confirmed by morphometric and statistical study as revealed below (Table II).

In the control group, faint reaction was found in the cytoplasm of the renal cells (Fig. 5A). Group II showed mild immunopositive stain for caspase-3 was found in the cytoplasm of renal cells (Fig. 5B). Group III revealed an increase in the intensity for caspase-3 (Fig. 5C). Group IV showed Intense immunopositive stain for caspase-3 was found in the cytoplasm of renal cells (Fig. 5D). These results were confirmed by morphometric and statistical study as revealed below (Table II).

Quantitative morphometric measurements. A significant elevation in the area percentage TNF- $\alpha$ immunostaining was found in groups: II, III and IV compared with the control group. In addition, a significant elevation in the area percentage caspase-3 immunostaining was found in groups: II, III and IV compared with the control group (Table II).

Table II. Quantitative morphometric measurements of mean area percentage of immunostaining for TNF- $\alpha$ and caspase- 3 expression.

\begin{tabular}{lcccc}
\hline & Control group I & Group II & Group III & Group IV \\
& $\mathrm{N}=10$ & $\mathrm{~N}=10$ & $\mathrm{~N}=10$ & $\mathrm{~N}=10$ \\
\hline TNF- $\alpha$ area [\%] & $0.115 \pm 0.022$ & $0.221 \pm 0.028$ & $0.227 \pm 0.019$ & $0.269 \pm 0.025$ \\
& & $\mathrm{P}<0.0001$ & $\mathrm{P}<0.0001$ & $\mathrm{P}<0.0001$ \\
Caspase-3 area [\%] & $2.1 \pm 0.006$ & $6.4 \pm 0.017$ & $8.3 \pm 0.020$ & $11.5 \pm 0.005$ \\
& & $\mathrm{P}<0.0001$ & $\mathrm{P}<0.0001$ & $\mathrm{P}<0.0001$ \\
\hline
\end{tabular}

Values are presented as mean \pm standard deviation (P: significance vs. control group).

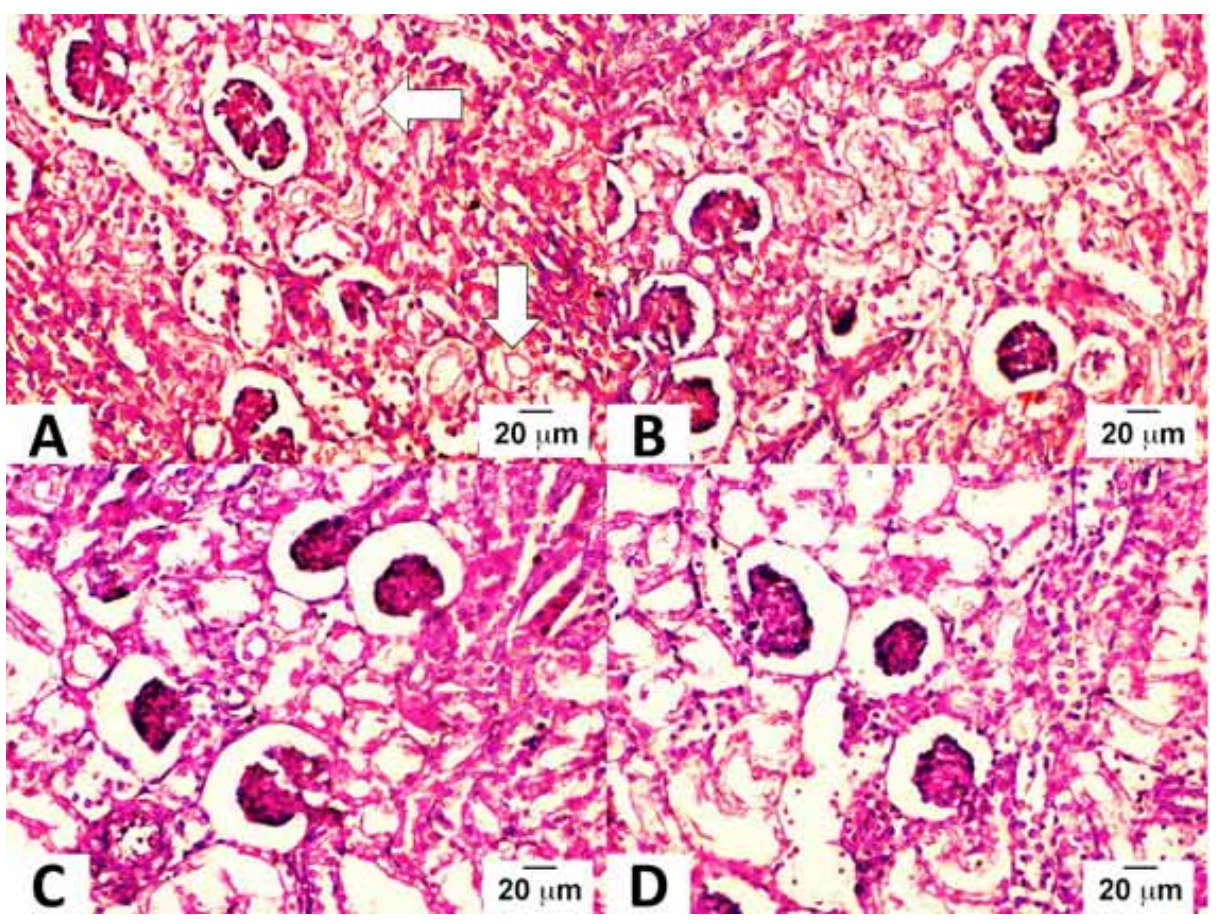

880
Fig. 2. (A). Photomicrograph of the control group showed kidney section of control rat showing positive PAS reaction in the renal tubules and the brush border is intact (arrow). (B). Section of group II revealed decrease of total carbohydrates in most of the cells. (C). Section of group III showed more reduction of total carbohydrates. (D). Section of group IV revealed severe damage of the proximal convoluted tubules with more decrease of the glycogen content (PAS. Scale bar $20 \mu \mathrm{m}$ ). 


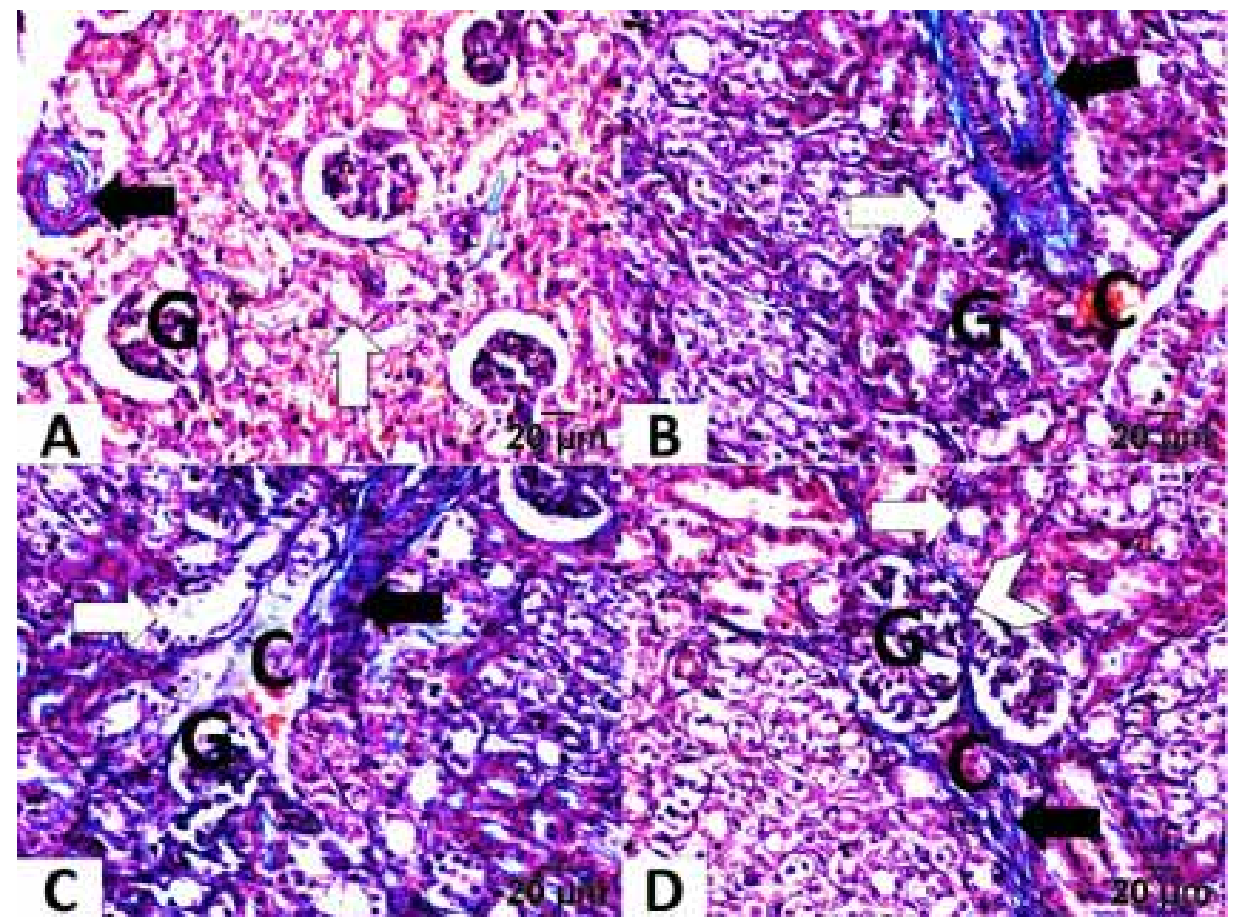

Fig. 3. (A). Photomicrograph of kidney section of the control group showed faint collagen fibers in the glomeruli $(\mathrm{G})$, around the tubules (white arrow) and around the capillaries (black arrow). (B). Section of group II revealed mild glomerular (G) collagen fibers, apparent collagen deposition around the blood vessels (black arrow) and no notable change in convoluted tubules (white arrow) with apparent congested blood (C). (C). Section of group III showed mild glomerular (G) collagen fibers, well-apparent collagen deposition in-between and around the tubules (white arrow) and around the blood vessels (black arrow) with apparent congested blood (C). (D). Section of group IV revealed moderate condensation of collagen fibers around the glomeruli $(\mathrm{G})$ (arrowhead), around convoluted tubules (white arrow), apparent collagen deposition around the blood vessels (black arrow) with congested blood (C) (Masson's Trichrome. Scale bar $20 \mu \mathrm{m}$ ).

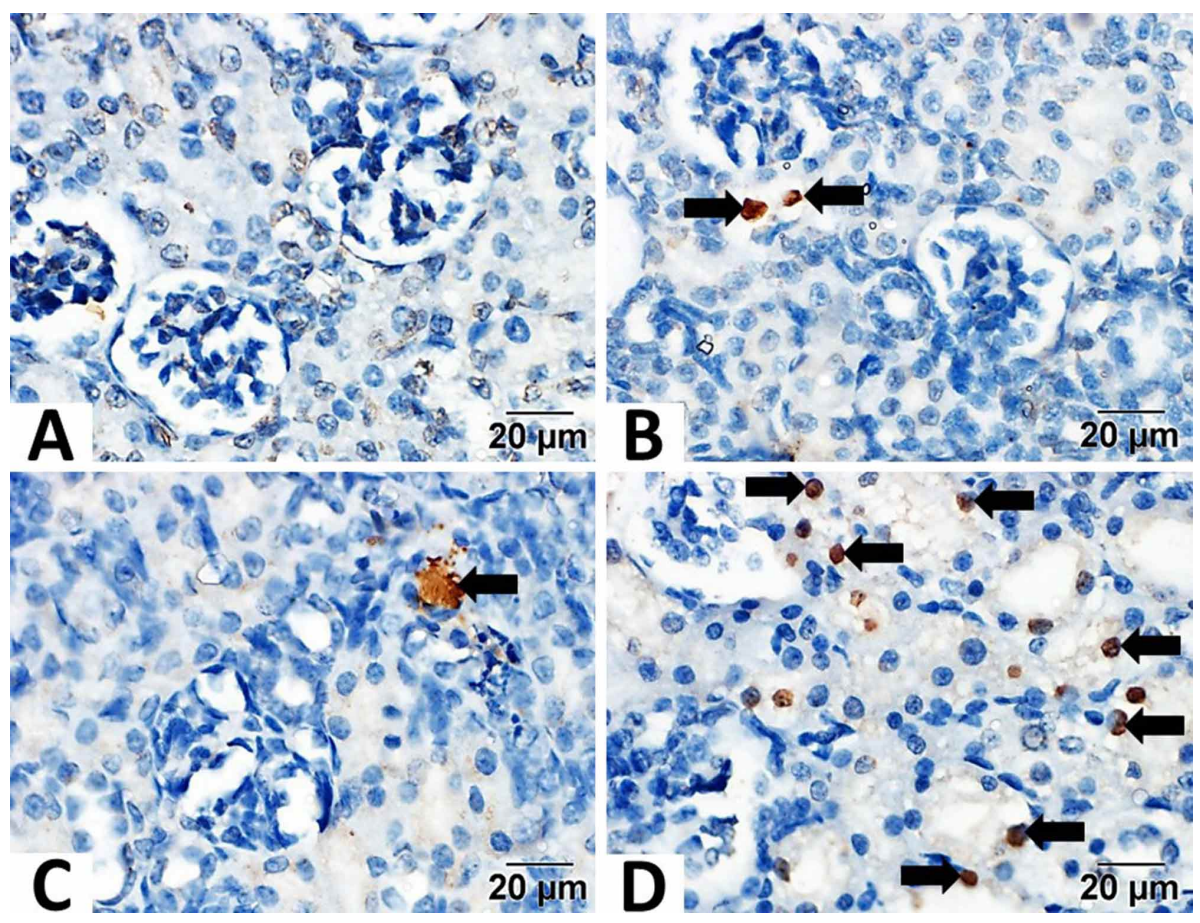

Fig. 4. TNF- $\alpha$ immunoexpression; (A). Section of the control group showed faint immunostaining of TNF$\alpha$. (B). Section of group II showed mild immunostaining for TNF- $\alpha$ (arrow). (C). Section of group III showed apparent increase in the intensity of immunostaining for TNF$\alpha$ (arrow). (D). Section of group IV showed intense positive immunostained areas (arrow) (Scale bar $20 \mu \mathrm{m})$. 


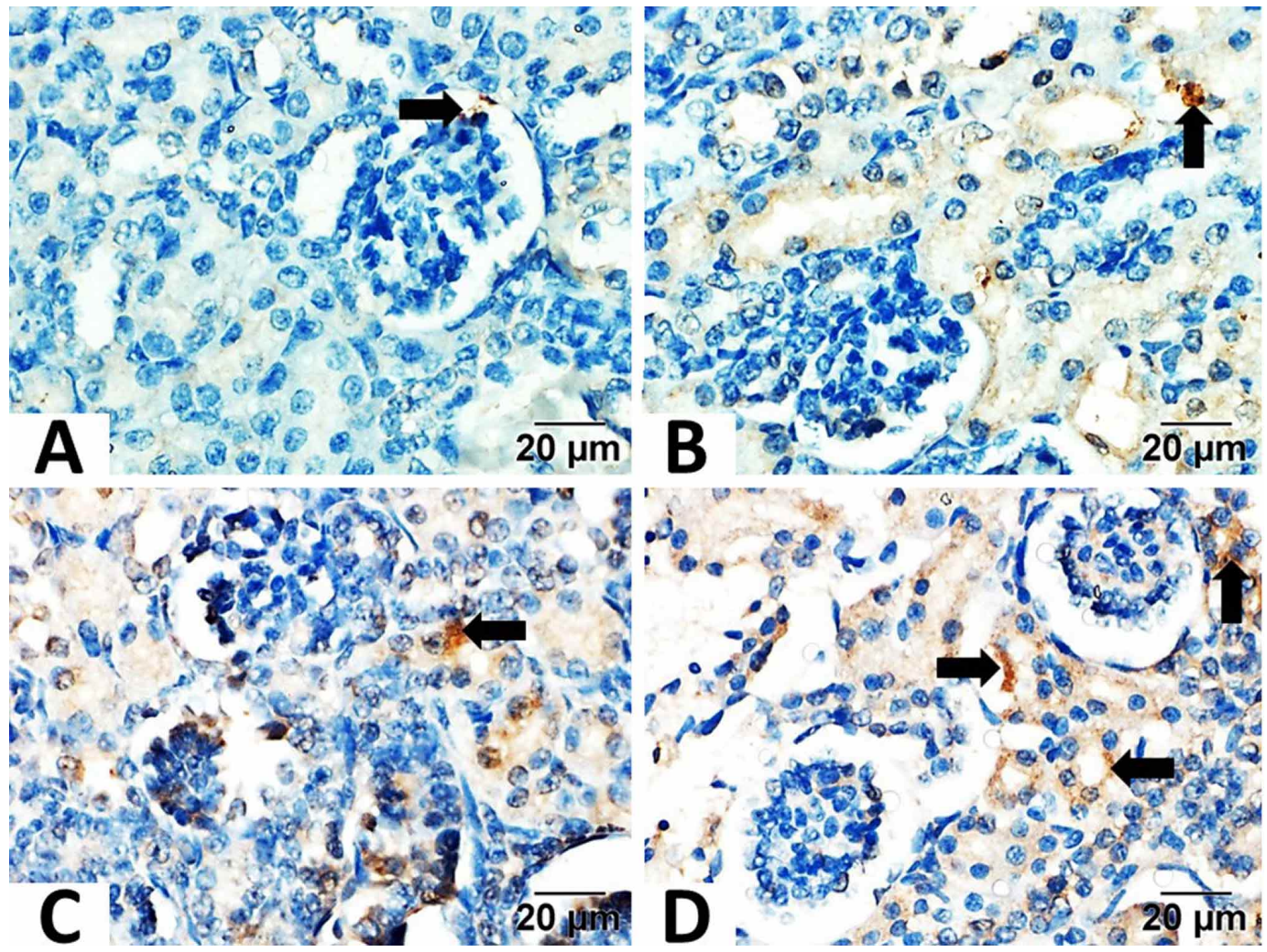

Fig. 5. Caspase-3 immunoexpression; (A). Control group showed faint immunostaining. (B). Section of group II revealed mild caspase-3 expression (arrow). (C). Section of group III showed increase in the intensity of caspase-3 expression (arrow). (D). Section of group IV showed intense positive caspase-3 expression (arrow) reveal apoptosis of the tubular cell (Scale bar $20 \mu \mathrm{m})$.

\section{DISCUSSION}

DS usually inhibits cyclooxygenase enzyme so affecting prostaglandin synthesis. That compound participates in different physiological processes of the kidney as glomerular filtration, tubular transport and renin release (Dunn, 2013). The pathophysiological process of renal dysfunction promoted by DS is indorsed by prostaglandin synthesis deterioration (Yasmeen et al., 2007).

DS administration increases the reactive oxygen species that encourage pro-oxidative damage in renal tissue with an increase in endogenous antioxidant enzymes as SOD levels (superoxide dismutase), malondialdehyde activity and reductions in glutathione peroxidase. That prevents $\mathrm{H} 2 \mathrm{O} 2$ conversion causing kidney damage (Aydin et al., 2003).

The histopathological effects in the current study are dose-dependent and a reflection of toxic damage due to exposure to DS are attributed to mitochondrial injury in the form of swelling and cristolysis (Taib et al., 2004). As DS has the affinity to bind with mitochondrial membranes, distorting the mitochondrial cristae, which play a key role in the functional integrity of this organelle (Sabry et al.). It is reported that DS causes inhibition of ATP synthesis, impair oxidative phosphorylation, calcium reflux induction and respiration stimulation in the mitochondria by investigators (Moreno-Sánchez et al., 1999).

The current findings suggested that proximal convoluted tubules were the frequently affected renal tubular cells, that attributed to cellular metabolic pathways are greatly vulnerable to nephrotoxic agents as DS (Elsayed et al., 2014). And this is supported by others observation (Sabry et al.).

DS-induced degeneration, widening, necrosis may be associated with ischemia caused by inhibition of prostaglandins synthesis in renal arterioles causing their constriction (Yasmeen et al.). In addition, DS induces 
necrosis of endothelial cells in the renal corpuscles (Triebskorn et al., 2004). Tubules necrosis and atrophy is attributed to DS resulted in transient shedding in renal tubular cells (Andalib et al., 2011).

Mononuclear cell infiltration noticed in the current study may be attributed to cyclooxygenase enzyme reduction that causes shifting of arachidonic acid precursor into lipoxygenase pathway, favoring inflammation creation encouraging metabolites of eicosapentaenoic acid that behaves as lympho-kinase, causing perpetuation of the inflammatory process and T-lymphocytes recruitment (ElMaddawy \& El-Ashmawy, 2013). DS induced membranous glomerulopathy is accompanied by creation of neutrophil chemotactic factors. This explain neutrophils lodgment in the glomerular capillaries, which can induce renal glomerular damage through release of their lytic enzymes (Nawaz et al., 2013).

In the current study, caspase- 3 immunoreactivity, as an indicator of apoptosis, was increased. This agreed with other work that found DS activates caspase- 3 and attributed that to oxidative stress with release of reactive oxygen species (ROS) subsequently (Gómez-Lechón et al., 2003). Apoptotic stimuli cause release of cytochrome-c from mitochondria that encourages a series of reactions, causing activation of caspase, which leads to consequent cell death (Servais et al., 2008). Accumulating suggestions propose that apoptosis plays a crucial role in numerous mechanisms of renal injury (Bae et al., 2009).

TNF- $\alpha$ exerts pro-inflammatory effects (e.g., endothelial apoptosis, induction of oxidative stress, upregulation of adhesion molecules and chemokines) (Pinheiro $\&$ Calixto, 2002). In agreement with the current study, researchers found that DS (strongest nonselective inhibitor of the cyclooxygenase [COX]) caused increased levels of TNF- $\alpha$. And the degree of the COX inhibition is correlated with increasing levels of TNF- $\alpha$ (Cagiltay et al., 2015). It is reported that strongest prostaglandin synthetase inhibitors as DS causes increase levels of TNF- $\alpha$ (Lundstam et al., 1982; Niederberger et al., 2004).

The obtained histopathological data showed that DS effects are dose-dependent manner as the severity of the lesion increased with the increase of the dose of DS. Based on the current findings, it is practical to elevate a warning for patients in the prenatal period treated with DS considering the resulting renal tissue alterations.

In conclusion, in light of our findings, DS may lead to adverse effects that are dose-dependent in the prenatally subjected kidney to this drug.
MUSTAFA, H. N.; ALKAN, I.; DENIZ, Ö, G.; ALTUNKAYNAK, B. Z.; ANNAÇ, E. \& KAPLAN, S. Estudio sobre el efecto tóxico de diferentes dosis de diclofenaco sódico en el desarrollo del riñón en el período postnatal. Int. J. Morphol., 37(3):877-884, 2019.

RESUMEN: Se investigaron los efectos tóxicos de diferentes dosis de diclofenaco sódico (DS) en el riñón de ratas, durante su período postnatal (0-7 días), por métodos morfométricos e inmunohistoquímicos. Para este propósito, se utilizaron 20 crías macho, de ratas Wistar albinas, y se dividieron en 5 grupos principales. El grupo Ia sirvió como control normal, el grupo fisiológico Ib recibió solución salina normal, el grupo II recibió una dosis baja de DS (3,9 mg/kg), el grupo III recibió una dosis media de DS $(9 \mathrm{mg} / \mathrm{kg})$ y el grupo IV recibió una dosis alta de DS $(18 \mathrm{mg} / \mathrm{kg})$. Se administraron los medicamentos de 0 a 7 días después del nacimiento de las ratas. En el octavo día de vida postnatal, todos los animales fueron sacrificados. Luego, se analizaron las muestras de riñón. Mediante hematoxilina-eosina se evidenció degeneración y necrosis, aparente atrofia de los glomérulos, infiltración de células mononucleares, vasos congestionados, aumento del tejido fibroso y distorsión de los túbulos contorneados proximales, con interrupción del margen en cepillo del grupo tratado con DS. Se detectó un aumento del nivel de caspasa- 3 y regulación al alza de TNF- $\alpha$ con diferentes dosis de DS. A la luz de nuestros hallazgos, la DS puede provocar efectos adversos en el riñón, que dependen de la dosis de este medicamento administrada en el período posnatal.

PALABRAS CLAVE: Diclofenaco sódico; Túbulos contorneados proximales; Apoptosis; Ciclooxigenasa.

\section{REFERENCES}

AbdEl-Moniem, M.; Mustafa, H. N.; Megahed, H. A.; Agaibyi, M. H.; Hegazy, G. A. \& El-Dabaa, M. A. The ameliorative potential of Hyphaene thebaica on streptozotocin-induced diabetic nephropathy. Folia Morphol. (Warsz), 74(4):447-57, 2015.

Andalib, S.; Naeini, A. M.; Garjani, A.; Asl, N. A. \& Abdollahi, A. A comparative study pertaining to deleterious effects of diclofenac sodium and meloxicam on kidney tissue in rats. EXCLI J., 10:149-54, 2011.

Aydin, G.; Gökçimen, A.; Öncü, M.; Çiçek, E.; Karahan, N. \& Gökalp, O. Histopathologic changes in liver and renal tissues induced by different doses of diclofenac sodium in rats. Turk. J. Vet. Anim. Sci., 27:1131-40, 2003.

Bae, E. H.; Lee, J.; Ma, S. K.; Kim, I. J.; Frøkiaer, J.; Nielsen, S.; Kim, S. Y. \& Kim, S. W. alpha-Lipoic acid prevents cisplatin-induced acute kidney injury in rats. Nephrol. Dial. Transplant., 24(9):2692-700, 2009.

Bhagat, H.; Malhotra, K.; Tyagi, C.; Gangwar, N. \& Pal, N. Evaluation of preoperative rectal diclofenac for perioperative analgesia in ENT surgery. Indian J. Anaesth., 47(6):463-6, 2003.

Cagiltay, E.; Kaplan, M.; Nalbant, S.; Akpak, Y. K.; Sahan, B. \& Akmaz, I. Does non-steroidal anti-inflammatory drugs increase tumor necrosis factor-alpha levels? Int. J. Res. Med. Sci., 3(9):2280-3, 2015.

Dunn, M. (Ed.). Prostaglandins and the Kidney. Biochemistry, Physiology, Pharmacology, and Clinical Applications. Springer US, 2013.

El-Maddawy, Z. K., \& El-Ashmawy, I. M. Hepato-renal and hematological effects of diclofenac sodium in rats. Global J. Pharmacol., 7(2):12332, 2013. 
Elsayed, M. G.; Elkomy, A. A.; Gaballah, M. S. \& Elbadawy, M. Nephrotoxicity of cefepime: A new cephalosporin antibiotic in rats. $J$. Pharmacol. Pharmacother., 5(1):33-8, 2014.

Farag, M. M.; Mikhail, M.; Shehata, R.; Abdel-Meguid, E. \& Abdel-Tawab, $\mathrm{S}$. Assessment of gentamicin-induced nephrotoxicity in rats treated with low doses of ibuprofen and diclofenac sodium. Clin. Sci. (Lond.), 91(2):187-91, 1996.

Gómez-Lechón, M. J.; Ponsoda, X.; O'Connor, E.; Donato, T.; Castell, J. V. \& Jover, R. Diclofenac induces apoptosis in hepatocytes by alteration of mitochondrial function and generation of ROS. Biochem. Pharmacol., 66(11):2155-67, 2003.

Katzung, B. G. \& Trevor, A. J. Basic \& Clinical Pharmacology. $13^{\text {th }}$ ed. New York, McGraw-Hill Education, 2016.

Lundstam, S. O.; Leissner, K. H.; Wåhlander, L. A. \& Kral, J. G. Prostaglandin-synthetase inhibition with diclofenac sodium in treatment of renal colic: comparison with use of a narcotic analgesic. Lancet, 1(8281):1096-7, 1982.

Mehinto, A. C.; Hill, E. M. \& Tyler, C. R. Uptake and biological effects of environmentally relevant concentrations of the nonsteroidal antiinflammatory pharmaceutical diclofenac in rainbow trout (Oncorhynchus mykiss). Environ. Sci. Technol., 44(6):2176-82, 2010.

Moreno-Sánchez, R.; Bravo, C.; Vásquez, C.; Ayala, G.; Silveira, L. H. \& Martı'nez-Lavi'n, M. Inhibition and uncoupling of oxidative phosphorylation by nonsteroidal anti-inflammatory drugs: study in mitochondria, submitochondrial particles, cells, and whole heart. Biochem. Pharmacol., 57(7):743-52, 1999.

Mustafa, H. N. Potential alleviation of Chlorella vulgaris and Zingiber officinale on lead-induced testicular toxicity: an ultrastructural study. Folia Biol. (Krakow), 63(4):269-78, 2015.

Nawaz, F. A.; Larsen, C. P. \& Troxell, M. L. Membranous nephropathy and nonsteroidal anti-inflammatory agents. Am. J. Kidney Dis., 62(5):1012-7, 2013

Niederberger, E.; Manderscheid, C.; Grösch, S.; Schmidt, H.; Ehnert, C. \& Geisslinger, G. Effects of the selective COX-2 inhibitors celecoxib and rofecoxib on human vascular cells. Biochem. Pharmacol., 68(2):34150, 2004.

Oaks, J. L.; Gilbert, M.; Virani, M. Z.; Watson, R. T.; Meteyer, C. U.; Rideout, B. A.; Shivaprasad, H. L.; Ahmed, S.; Chaudhry, M. J.; Arshad, M.; et al. Diclofenac residues as the cause of vulture population decline in Pakistan. Nature, 427(6975):630-3, 2004.

Pinheiro, R. M. \& Calixto, J. B. Effect of the selective COX-2 inhibitors, celecoxib and rofecoxib in rat acute models of inflammation. Inflamm. Res., 51(12):603-10, 2002.

Sabry, S. A.; Sakr, S. M. \& Shahin, M. A. Histological and ultrastructural studies on the effect of diclofenac sodium on the renal cortex of fetuses of albino mice. Global J. Pharmacol., 8(3):369-77, 2014.

Servais, H.; Ortiz, A.; Devuyst, O.; Denamur, S.; Tulkens, P. M. \& MingeotLeclercq, M. P. Renal cell apoptosis induced by nephrotoxic drugs: cellular and molecular mechanisms and potential approaches to modulation. Apoptosis, 13(1):11-32, 2008.

Taib, N. T.; Jarrar, B. M. \& Mubarak, M. M. Ultrastructural alterations in renal tissues of rabbits induced by diclofenac sodium (Voltaren). Saudi Med. J., 25(10):1360-5, 2004.

Triebskorn, R.; Casper, H.; Heyd, A.; Eikemper, R.; Köhler, H. R. \& Schwaiger, J. Toxic effects of the non-steroidal anti-inflammatory drug diclofenac. Part II: cytological effects in liver, kidney, gills and intestine of rainbow trout (Oncorhynchus mykiss). Aquat. Toxicol., 68(2):15166, 2004.

Yasmeen, T.; Qureshi, G. S. \& Perveen, S. Adverse effects of diclofenac sodium on renal parenchyma of adult albino rats. J. Pak. Med. Assoc., 57(7):349-51, 2007
Corresponding author:

Dr. Hesham N. Mustafa

Department of Anatomy

Faculty of Medicine

King Abdulaziz University

PO Box 80205

JEDDAH 21589

SAUDI ARABIA

Email: hesham977@hotmail.com

Received: 02-02-2019

Accepted: 28-03-2019 